\title{
MED27 Variants Cause Developmental Delay, Dystonia, and Cerebellar Hypoplasia
}

\section{Meng, Linyan}

2021-04

Meng , L , Isohanni , P , Shao , Y , Graham , B H , Hickey , S E , Brooks , S , Suomalainen , A , Joset , P , Steindl , K, Rauch , A , Hackenberg , A, High , F A , Armstrong-Javors , A , Mencacci , N E , Gonzalez-Latapi , P , Kamel , W A, Al-Hashel , J Y , Bustos , B , Hernandez , A , Krainc , D , Lubbe , S J , Van Esch, H, De Luca , C, Ballon, K, Ravelli , C , Burglen , L, Qebibo , L, Calame , D G, Mitani , T, Marafi , D , Pehlivan , D, Saadi , N W , Sahin , Y, Maroofian , R, Efthymiou, S, Houlden, H, Maqbool , S, Rahman , F , Gu , S , Posey , J E , Lupski , J R , Hunter , J , Wangler , M F , Carroll , C J \& Yang , Y 2021 , ' MED27 Variants Cause Developmental Delay, Dystonia, and Cerebellar Hypoplasia ' , Annals of Neurology, vol. 89 , no. 4 , pp. 828-833 . https://doi.org/10.1002/ana.26019

http://hdl.handle.net/10138/340557

https://doi.org/10.1002/ana.26019

acceptedVersion

Downloaded from Helda, University of Helsinki institutional repository.

This is an electronic reprint of the original article.

This reprint may differ from the original in pagination and typographic detail.

Please cite the original version. 


\section{MED27 variants cause Developmental Delay, Dystonia, and Cerebellar Hypoplasia}

Running head: MED27 associated with novel neurodevelopmental syndrome

Linyan Meng, $\mathrm{PhD}^{1,2^{*}}$, Pirjo Isohanni, MD, $\mathrm{PhD}^{3,4}$, Yunru Shao, MS ${ }^{1,5,6}$, Brett H. Graham, MD, $\mathrm{PhD}^{7}$, Scott E. Hickey, $\mathrm{MD}^{8}$, Stephanie Brooks, $\mathrm{MS}^{8}$, Anu Suomalainen, $\mathrm{PhD}^{3}$, Pascal Joset, $\mathrm{PhD}^{9}$, Katharina Steindl, $\mathrm{MD}^{9}$, Anita Rauch, $\mathrm{PhD}^{9}$, Annette Hackenberg, $\mathrm{MD}^{10}$, Frances A. High, MD, PhD ${ }^{11,12}$, Amy Armstrong-Javors, MD ${ }^{12,13}$, Niccolò E. Mencacci, MD, PhD ${ }^{14,15}$, Paulina Gonzàlez-Latapi, MD ${ }^{14}$, Walaa A. Kamel, MD ${ }^{16,17}$, Jasem Y.Al-Hashel, MD ${ }^{16,18}$, Bernabé I. Bustos, PhD ${ }^{14,15}$, Alejandro V. Hernandez, $\mathrm{BS}^{14}$, Dimitri Krainc, MD, PhD ${ }^{14,15}$, Steven J. Lubbe, $\mathrm{PhD}^{14,15}$, Hilde Van Esch, MD ${ }^{19}$, Chiara De Luca, $\mathrm{MD}^{19}$, Katleen Ballon, MD ${ }^{20}$, Claudia Ravelli, $\mathrm{MD}^{21}$, Lydie Burglen, $\mathrm{MD}, \mathrm{PhD}^{22,23}$, Leila Qebibo, $\mathrm{MD}^{22}$, Daniel G. Calame, $\mathrm{MD}, \mathrm{PhD}^{1,6,24}$, Tadahiro Mitani, MD, $\mathrm{PhD}^{1}$, Dana Marafi, $\mathrm{MD}^{1,25}$, Davut Pehlivan, $\mathrm{MD}^{1,6,24}$, Nebal Waill Saadi, MD ${ }^{26,27}$, Yavuz Sahin, MD ${ }^{28}$, Reza Maroofian, $\mathrm{PhD}^{29}$, Stephanie Efthymiou, MD ${ }^{29}$, Henry Houlden, $M D^{29}$, Shazia Maqbool, MD ${ }^{30}$, Fatima Rahman, $M D^{30}$, Shen $G u, P^{31}$, Jennifer $E$

Posey, MD, $\mathrm{PhD}^{1}$, James R. Lupski, MD, PhD, DSc (hon) ${ }^{1,5,6,32}$, Jill V. Hunter, $\mathrm{MD}^{33,34}$, Michael F. Wangler, MD, $\mathrm{PhD}^{1,4,35}$, Christopher J Carroll, $\mathrm{PhD}^{3,36}$, Yaping Yang, $\mathrm{PhD}^{1,2^{\star * *}}$

1. Department of Molecular and Human Genetics, Baylor College of Medicine, Houston, TX, USA.

2. Baylor Genetics, Houston, TX, USA.

3. Research Programs Unit, Stem Cells and Metabolism, Faculty of Medicine, University of Helsinki, Helsinki, Finland

4. Department of Child Neurology, Children's Hospital, University of Helsinki and Helsinki University Hospital, Helsinki, Finland

5. Department of Pediatrics, Baylor College of Medicine, Houston, TX, USA. 
6. Texas Children's Hospital, Houston, TX, USA.

7. Department of Medical and Molecular Genetics, Indiana University School of Medicine, Indianapolis, Indiana, USA

8. Department of Pediatrics, The Ohio State University College of Medicine, Division of Genetic \& Genomic Medicine, Nationwide Children's Hospital, Columbus, OH, USA

9. Institute of Medical Genetics, University of Zurich, Schlieren-Zurich, Switzerland

10. Department of Pediatric Neurology, University Children's Hospital Zurich, University of Zurich, Switzerland

11. Division of Medical Genetics, Massachusetts General Hospital, Boston, MA

12. Harvard Medical School, Boston, MA

13. Department of Pediatric Neurology, Massachusetts General Hospital, Boston, MA

14. Ken and Ruth Davee Department of Neurology, Feinberg School of Medicine, Northwestern University, Chicago, IL

15. Simpson Querrey Center for Neurogenetics, Feinberg School of Medicine, Northwestern University, Chicago, IL

16. Department of Neurology, Ibn Sina Hospital, Kuwait City, Kuwait

17. Department of Neurology, Faculty of Medicine, Beni-Suef University, Egypt

18. Department of Medicine, Faculty of Medicine, Kuwait University, Kuwait

19. Centre for Human Genetics, University Hospitals Leuven, Herestraat 49, 3000 Leuven, Belgium

20. Centre for Developmental Disabilities, University Hospitals Leuven, Herestraat 49, 3000 Leuven, Belgium

21. Pediatric neurology Department, Neurogenetics Reference Center, I-motion Institut, APHP.Sorbonne Université, Armand Trousseau Hospital, Paris, France 
22. Cerebellar Malformations and Congenital diseases Reference Center and Neurogenetics Lab, Department of Genetics, AP-HP.Sorbonne Université, Armand Trousseau Hospital, Paris, France

23. Developmental Brain Disorders Laboratory, Imagine Institute, INSERM UMR 1163, Paris, France

24. Division of Neurology and Developmental Neuroscience, Department of Pediatrics, BCM, Houston, TX 77030, USA

25. Department of Pediatrics, Faculty of Medicine, Kuwait University, P.O. Box 24923, 13110 Safat, Kuwait

26. College of Medicine, Baghdad University, Iraq

27. Children Welfare Teaching Hospital, Baghdad, Iraq

28. Department of Medical Genetics, Genoks Genetic Center, Ankara, Turkey

29. Department of Neuromuscular Disorders, UCL Institute of Neurology, London WC1N 3BG, UK

30. Development and Behavioural Pediatrics Department, Institute of Child Health and The Children Hospital, Lahore, Pakistan

31. School of Biomedical Sciences, The Chinese University of Hong Kong, Shatin, Hong Kong S.A.R

32. Human Genome Sequencing Center, Baylor College of Medicine, Houston, Texas, 77030, USA

33. EB Singleton Department of Pediatric Radiology, Texas Children's Hospital, TX, USA

34. Department of Radiology, Baylor College of Medicine, Houston, TX, USA

35. Jan and Dan Neurological Research Institute, Texas Children's Hospital, Houston, TX, USA.

36. Molecular and Clinical Sciences Research Institute, St. George's, University of London, Cranmer Terrace, London, SW17 ORE, UK. 
${ }^{*}$ co-corresponding authors

${ }^{* *}$ Current address: AiLife Diagnostics, 1920 Country Place Suite 100, Pearland, TX, USA.

Linyan Meng,

Department of Molecular and Human Genetics

Baylor College of Medicine

Houston, TX 77030.

Tel: 281.849 .8871

Email: Imeng@bcm.edu

Yaping Yang

Department of Molecular and Human Genetics

Baylor College of Medicine

Houston, TX 77030

Email: yapingy@ailifeus.com

Number of characters in the title: 77

Number of characters in the running head: 50 
Number of words in the Abstract: 96

Number of words in the Introduction: 162

Number of words in the Discussion: 378

Number of words in the body of manuscript: 1409

Number of figures: 2

Number of colored figures: 0

Number of tables: 1

Key words: MED27, neurodevelopmental syndrome 


\begin{abstract}
The Mediator multiprotein complex functions as a regulator of RNA polymerase II-catalyzed gene transcription. In this study, exome sequencing (ES) detected biallelic putative diseasecausing variants in MED27, encoding Mediator Complex Subunit 27, in sixteen patients from eleven families with a novel neurodevelopmental syndrome. Patient phenotypes are highly homogeneous including global developmental delay, intellectual disability, axial hypotonia with distal spasticity, dystonic movements, and cerebellar hypoplasia. Seizures and cataracts were noted in severely affected individuals. Identification of multiple patients with biallelic MED27 variants supports the critical role of MED27 in normal human neural development, particularly for the cerebellum.
\end{abstract}




\section{INTRODUCTION}

The Mediator complex acts as a bridge between transcription factors at enhancers and the basal transcriptional machinery at specific promoters, thereby stabilizing the preinitiation complex and stimulating promoter release ${ }^{1,2}$. It is also involved in additional aspects of transcriptional regulation, including mRNA and noncoding RNA processing, chromatin remodeling and epigenetic regulation ${ }^{3}$. MED12 was the first human disease gene discovered in the Mediator complex, associated with Opitz-Kaveggia syndrome (MIM: 305450) and LujanFryns syndrome (MIM: 309520) ${ }^{4,5}$. Since then, a total of six genes in the complex have been reported as disease genes mostly in association with neurodevelopmental disorders. However, the majority of the Mediator genes remain without disease associations.

Here, we report a novel neurodevelopmental syndrome with a unique phenotype of global developmental delay, axial hypotonia with appendicular spasticity, dystonic movements, cerebellar hypoplasia, epilepsy, and cataracts. Exome sequencing detected biallelic diseasecausing variants in MED27 (MIM: 605044), a eukaryotic specific subunit thought to represent an ortholog of budding yeast Med3 ${ }^{6,7}$.

\section{PATIENTS AND METHODS}

Patients were identified through GeneMatcher and all subjects were examined by the referring physicians $^{8}$. Clinical information including medical notes, facial photos, and MRI images were collected, critically reviewed and compared. Informed consents were obtained from the legal guardians of all subjects. The study was performed in accordance with the guidelines specified by the Institutional Review Boards and Ethics Committees at each institution.

Exome sequencing (ES) on each patient was performed in commercial or academic laboratories per each laboratory's protocol. Targeted Sanger sequencing was performed in probands and 
available relatives to validate variant segregation. Variant filtering and prioritization were performed by assessing variant characteristics including general population frequency, variant severity, in silico prediction, inheritance modeling, pathway analysis, and family segregation analysis. MED27 variants were annotated on reference sequence NM_004269.3.

\section{RESULTS}

Prior to ES analysis, most reported patients had extensive clinical, metabolic, and genetic investigations, yet had not received a molecular diagnosis. ES analysis followed by targeted Sanger sequencing revealed biallelic variants, either compound heterozygous or homozygous alleles, in MED27 in sixteen affected individuals (Supplementary Table 1). A total of eleven unique MED27 variants were identified, including frameshift (3/11), canonical splice-site (1/11), and missense variants (7/11) (Fig 1, Supplementary Table 2). Three recurrent variants [c.776C>T (p.Pro259Leu), c.839C>T (p.Pro280Leu), and c.871G>A (p.Gly291Ser)] affecting CpG sites were identified in multiple families with different ethnic backgrounds. All MED27 variants are either absent or rare in the Genome Aggregation Database (gnomAD v2). The variants occurred at residues that are extremely conserved from human to drosophila with GERP++ RS score greater than $5.0^{9}$. Multiple in silico programs including PolyPhen2, SIFT ${ }^{1}$, Mutation Taster and CADD (Combined Annotation Dependent Depletion) support the deleterious effect of these variants (Supplementary Table 2). ${ }^{10,11,12,13}$ Notably, six out of seven missense variants are located in close proximity near the C-terminal end of the protein (Fig 1).

The clinical phenotypes of each subject are summarized in Table 1 and Supplementary Table 3. The reported cohort consists of 13 pediatric patients (ages 0 to 13 years) and three adult patients (ages 26, 36, and 42 years). Consanguinity was noted by historical report in five of the eleven families. Except for one subject born preterm (11-2), all were born full term with no perinatal complications. Patient $10-2$, who was previously published in a large arthrogryposis 
cohort study, had a dual molecular diagnosis with homozygous pathogenic variants in both MED27 and COG6, the latter of which is associated with a congenital disorder of glycosylation type III (MIM: 614576). ${ }^{14}$ The severe clinical symptoms and early death of this individual were most likely attributable to the COG6 variant and may have masked the MED27-related phenotype. Therefore, this individual was excluded from clinical analysis.

Global developmental delay, ranging from mild to profound, and intellectual disability were observed in all patients. Eight patients were severely affected and were non-verbal and unable to sit or walk independently. Among them, two patients $(2,3-2)$ also had motor regression. Five patients were moderately delayed developmentally but achieved ambulation and some expressive language. Two siblings (6-1, 6-2) were reported to have normal development until 89 years old when both demonstrated progressive difficulties with ambulation, speech articulation, writing, and school performance. Motor and cognitive symptoms progressed until the late teenage years and recent neurocognitive testing demonstrated moderate intellectual disability.

Axial hypotonia was noted in $93.3 \%(14 / 15)$ of patients. Appendicular spasticity and dystonic movements were seen in $86.7 \%$ (13/15). These symptoms were especially prominent in two siblings (6-1, 6-2) who experienced generalized dystonia and moderate dysarthria due to involvement of the oromandibular muscles.

Brain MRI demonstrated cerebellar hypoplasia involving the vermis more than the cerebellar hemispheres in $86.7 \%$ of patients (Fig 2). Multiple severely affected patients $(3-1,3-2,4,5)$ had strikingly severe vermian hypoplasia. In some patients, additional brain abnormalities were observed, including hypomyelination (5), cerebral atrophy (3-1, 3-2), thin corpus callosum (3-1, 3-2, 5), and enlarged ventricles (5, 7). Progressive atrophy involving the cerebrum, cerebellum 
and/or basal ganglia was seen in four patients (2, 3-1, 4 and 5). Microcephaly was present in $28.6 \%$ of patients $(4 / 14,2,3-1,3-2,5)$.

Epilepsy was present in $60.0 \%$ (9/15) of patients with an age of onset ranging from 20 days to 5 years. Reported seizure types were varied and included focal motor seizures $(3 / 7 ; 43 \%)$, generalized tonic-clonic seizures $(2 / 7 ; 29 \%)$, hemifacial clonic seizures $(2 / 7 ; 29 \%)$, generalized myoclonic seizures $(1 / 7 ; 14 \%)$, epileptic (infantile) spasms $(1 / 7 ; 14 \%)$, atonic seizures $(1 / 7$; $14 \%)$ and atypical absence seizures (1/7; 14\%). Epilepsy was drug-resistant in $3 / 9(33 \%)$ and drug-responsive in 5/9 (56\%). One patient with seizures was not treated with anti-epileptic drugs (AEDs). Two of the subjects with drug-resistant epilepsy experienced multiple seizures daily. AEDs that were trialed included valproate (5/9), levetiracetam (3/9), clobazam (2/9), gabapentin (1/9), carbamazepine (1/9), phenobarbital (1/9), topiramate (1/9), and vigabatrin (1/9). The combination of valproate and levetiracetam or clobazam was reported to be effective in three patients $(8-1,8-2,11-1)$.

Cataracts were present in $66.7 \%(10 / 15)$ of patients. Four reported mature cataracts and two had posterior cataracts. Feeding difficulties were present in seven patients, with one individual (2) requiring G-tube placement. Dysmorphic features were reported in some patients (Supplementary Table 1 and 3), though no recognizable facial gestalt or pattern was appreciated.

\section{DISCUSSION}

We report sixteen patients with a novel autosomal recessive disease due to pathogenic variants in MED27 consisting of global developmental delay, axial hypotonia, spastic tetraplegia, dystonia, cerebellar hypoplasia, seizures, and cataracts (Table 1). Missense variants were more commonly identified than frameshift and splicing variants. Three missense variants associated 
with milder phenotypes [c.188T>G (p.Val63Gly), c.776C>T (p.Pro259Leu), and c.878C>T (p.Pro293Leu)]. The c.188T>G variant is distinct as it is the only missense variant located outside the C-terminal region where all other missense variants clustered (Fig 1).

The Mediator complex is composed of 25 (yeast) or 30 (human) subunits that form four modules: head, middle, tail, and CDK8 kinase ${ }^{2,15}$. MED27 is a metazoan-specific Mediator subunit sitting at the junction of the head and tail modules of the complex ${ }^{15}$. Med27/Crsp34 lossof-function in zebrafish disrupts dopaminergic amacrine cells and serotonergic neurons at 2.5 dpf (days post-fertilization) ${ }^{16}$. Mutant embryos had a reduction of head, eye, and jaw size, and died around $6 \mathrm{dpf}$. In flies, Med27 knockout caused lethality at the pupal stage ${ }^{17,18}$. Similarly, chickens carrying homozygous MED27 insertional truncating mutations were born at less than expected Mendelian ratios, suggesting partial embryonic lethality in homozygotes ${ }^{19}$. Although the specific biological function of MED27 remains unknown, it clearly plays an essential role in early embryonic and neuronal development.

Similar to the effect of knockout mutations, homozygous C-terminal Flag-tagged Med27 mutations were also lethal in fruit flies, suggesting a critical role of the MED27 C-terminal domain. ${ }^{18}$ In the patients reported here, 6/7 missense variants clustered near the C-terminus of the MED27 protein. One study indicated MED27 C-terminal domain has a C2-H2 zinc finger motif ${ }^{6}$. MED27 interacts extensively with multiple subunits in the head module, including MED17 ${ }^{20}$. Cryo-electron microscopy of the S. pombe head module reveals that Med27 connects Med18/20 with Med17 ${ }^{15}$. Interestingly, compared with other Mediator complexassociated diseases, MED27 and MED17-related diseases are most similar. Both are autosomal recessive and characterized by psychomotor developmental delay, spasticity, seizures, progressive microcephaly and cerebellar atrophy (Supplementary Table 4). One intriguing hypothesis would be that variants in MED27 disrupt its interaction with other Mediator 
complex subunits, such as MED17, leading to similar disease phenotypes. Additional studies on the functional consequence of MED27 variants are needed to further address the molecular mechanisms underlying the disease.

Acknowledgements: N.E.M. is supported by a Parkinson's foundation grant. P.I. is supported by Foundation for Pediatric Research. D.K. is supported by the Simpson Querrey Center for Neurogenetics. Biospecimens used in the analyses presented in this article were obtained from the Northwestern University Movement Disorders Center (MDC) Biorepository. As such, the investigators within MDC Biorepository contributed to the design and implementation of the MDC Biorepository and/or provided data and collected biospecimens but did not participate in the analysis or writing of this report. MDC Biorepository investigators include (Tanya Simuni, MD; Dimitri Krainc, MD PhD; Opal Puneet MD, PhD; Cindy Zadikoff, MD; Onur Melen, MD; Danny Bega, MD; Roneil G. Malkani, MD; Steven Lubbe, PhD; Niccolo E. Mencacci ,MD, PhD; Christina Zelano, PhD; Joanna Blackburn, MD; Firas Wehbe, MD, PhD; Lisa Kinsley, MS, CGC; Tina Ward, MS). A gift from the Malkin family generously supported the work of the MDC biorepository. We thank Finnish Institute for Molecular Medicine for whole-exome sequencing and Anu Harju and Max Pohjanpelto (University of Helsinki) for technical assistance. J.R.L. is supported by a grant from the National Human Genome Research Institute (NHGRI) and National Heart, Lung, and Blood Institute (NHBLI) to the Baylor-Hopkins Center for Mendelian Genomics (BHCMG, UM1 HG006542); a National Institute of Neurological Disorders and Stroke (NINDS) grant (R35NS105078); and an Muscular Dystrophy Association (MDA) grant (512848). T.M. is supported by the Uehara Memorial Foundation. D.M. is supported by a Medical Genetics Research Fellowship Program through the United States National Institute of Health (T32 GM007526-42). D.P. is supported by a Clinical Research Training Scholarship in Neuromuscular Disease partnered by the American Brain Foundation (ABF) and Muscle Study 
Group (MSG), and International Rett Syndrome Foundation (IRSF grant \#3701-1). J.E.P. was supported by NHGRI K08 HG008986.

\section{$\underline{\text { Author contributions }}$}

L.M. and Y.Y. contributed to study conception and design. L.M. drafted the manuscript text and prepared the figures. All authors contributed to patient clinical data and exome sequencing data acquisition and analysis, and manuscript review and revision.

\section{Potential Conflicts of Interest:}

L.M. is employee of Baylor Genetics, in which exome sequencing of patient 1 was performed. The Department of Molecular and Human Genetics at Baylor College of Medicine receives revenue from clinical genetic testing conducted at Baylor Genetics (BG) Laboratories. Other authors have no potential conflicts to report. 


\section{References}

1. Jeronimo C, Robert F. The Mediator Complex: At the Nexus of RNA Polymerase II Transcription. Trends Cell Biol. 2017 Oct;27(10):765-83.

2. Soutourina J. Transcription regulation by the Mediator complex. Nat Rev Mol Cell Biol. 2017 Dec 6.

3. Yin JW, Wang G. The Mediator complex: a master coordinator of transcription and cell lineage development. Development. 2014 Mar;141(5):977-87.

4. Risheg $\mathrm{H}$, Graham JM, Jr., Clark RD, et al. A recurrent mutation in MED12 leading to R961W causes Opitz-Kaveggia syndrome. Nat Genet. 2007 Apr;39(4):451-3.

5. Schwartz CE, Tarpey PS, Lubs HA, et al. The original Lujan syndrome family has a novel missense mutation (p.N1007S) in the MED12 gene. J Med Genet. 2007 Jul;44(7):472-7.

6. Bourbon HM. Comparative genomics supports a deep evolutionary origin for the large, four-module transcriptional mediator complex. Nucleic Acids Res. 2008 Jul;36(12):3993-4008.

7. Boube M, Joulia L, Cribbs DL, Bourbon HM. Evidence for a mediator of RNA polymerase II transcriptional regulation conserved from yeast to man. Cell. 2002 Jul 26;110(2):143-51.

8. Sobreira N, Schiettecatte F, Valle D, Hamosh A. GeneMatcher: a matching tool for connecting investigators with an interest in the same gene. Hum Mutat. 2015 Oct;36(10):928-

30 .

9. Davydov EV, Goode DL, Sirota M, Cooper GM, Sidow A, Batzoglou S. Identifying a high fraction of the human genome to be under selective constraint using GERP++. PLoS Comput Biol. 2010 Dec 2;6(12):e1001025.

10. Adzhubei IA, Schmidt S, Peshkin L, et al. A method and server for predicting damaging missense mutations. Nat Methods. 2010 Apr;7(4):248-9.

11. Vaser R, Adusumalli S, Leng SN, Sikic M, Ng PC. SIFT missense predictions for genomes. Nat Protoc. 2016 Jan;11(1):1-9.

12. Schwarz JM, Rodelsperger C, Schuelke M, Seelow D. MutationTaster evaluates disease-causing potential of sequence alterations. Nat Methods. 2010 Aug;7(8):575-6.

13. Rentzsch P, Witten D, Cooper GM, Shendure J, Kircher M. CADD: predicting the deleteriousness of variants throughout the human genome. Nucleic Acids Res. 2019 Jan 8;47(D1):D886-D94.

14. Pehlivan D, Bayram Y, Gunes N, et al. The Genomics of Arthrogryposis, a Complex Trait: Candidate Genes and Further Evidence for Oligogenic Inheritance. Am J Hum Genet. 2019 Jul 3;105(1):132-50.

15. Tsai KL, Yu X, Gopalan S, et al. Mediator structure and rearrangements required for holoenzyme formation. Nature. 2017 Apr 13;544(7649):196-201.

16. Durr K, Holzschuh J, Filippi A, et al. Differential roles of transcriptional mediator complex subunits Crsp34/Med27, Crsp150/Med14 and Trap100/Med24 during zebrafish retinal development. Genetics. 2006 Oct;174(2):693-705.

17. Gokcezade J, Sienski G, Duchek P. Efficient CRISPR/Cas9 plasmids for rapid and versatile genome editing in Drosophila. G3 (Bethesda). 2014 Sep 17;4(11):2279-82.

18. Li-Kroeger D, Kanca O, Lee PT, et al. An expanded toolkit for gene tagging based on MiMIC and scarless CRISPR tagging in Drosophila. Elife. 2018 Aug 9;7.

19. Tsujino K, Okuzaki Y, Hibino N, et al. Identification of transgene integration site and anatomical properties of fluorescence intensity in a EGFP transgenic chicken line. Dev Growth Differ. 2019 Sep;61(7-8):393-401.

20. Tsai KL, Tomomori-Sato C, Sato S, Conaway RC, Conaway JW, Asturias FJ. Subunit Architecture and Functional Modular Rearrangements of the Transcriptional Mediator Complex. Cell. 2014 Jul 17;158(2):463. 


\section{FIGURES}

Figure 1 Nucleotide and amino acid changes in patients with MED27 biallelic variants.

(A) Schematic representation of MED27 gene structure (not drawn to scale) and nucleotide position of eleven variants identified in eleven families. (B) Alignment of human MED27 protein sequence with other model organisms including mouse, rat, pig, bovine, Xenopus, zebrafish and Drosophila.

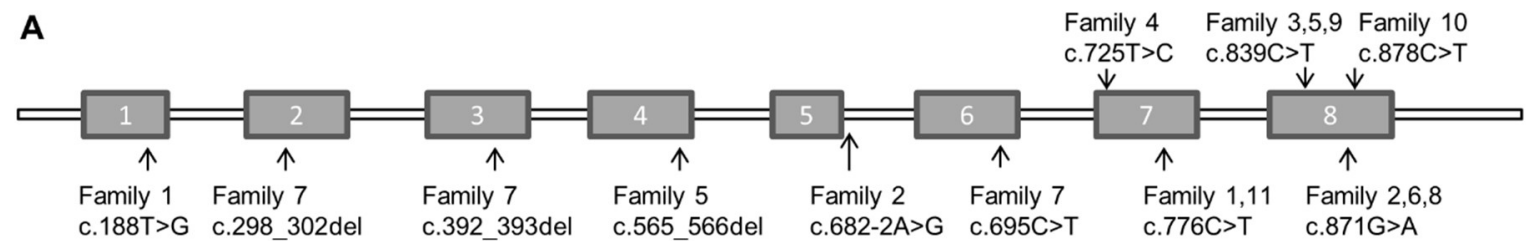

B

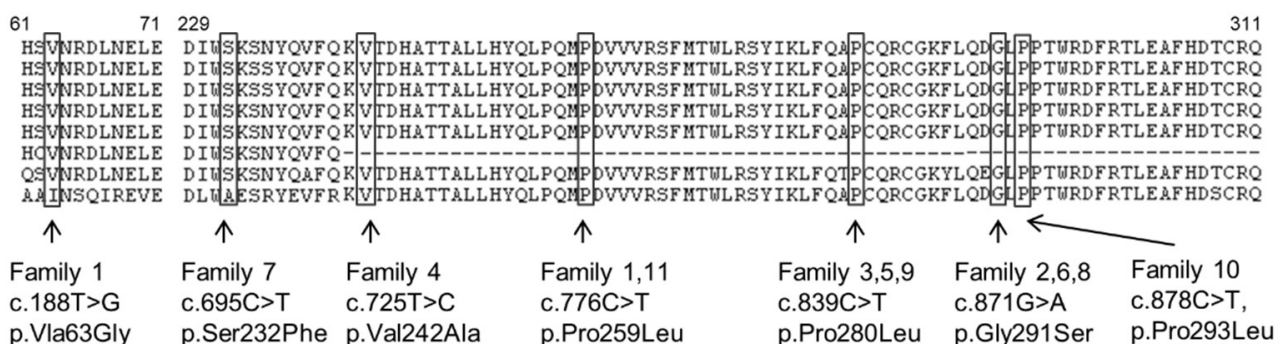

Figure 2 Brain imaging of patients with MED27 biallelic variants.

Brain imaging from ten patients. Sagittal T1 +/- coronal T2 brain MRI imaging of nine patients (A-K, M). Sagittal brain computed tomography $(C T)$ imaging is provided for patient $9(\mathrm{~L}) .(A)$ Patient 1 (2 years) showing mild cerebellar vermian hypoplasia (ARROW). (B) Patient 2 (2 years 11 months) showing normal-appearing corpus callosum and cerebellar vermian hypoplasia (ARROW). (C) Patient 3-1 (1 year) showing thin corpus callosum (ARROWHEAD) and severe cerebellar hypoplasia (ARROW). (D) Patient 3-1 (2 years 5 months), showing thin corpus callosum (ARROWHEAD) and progressive cerebellar atrophy (ARROW). (E) Patient 3-2 (11 years 9 months) showing thin corpus callosum (ARROWHEAD) and cerebellar vermian hypoplasia (ARROW) (F) Patient 4 (1 year), showing cerebellar vermian hypoplasia (ARROW). 
(G) Patient 4 (2 years 5 months) showing progressive cerebellar atrophy (ARROW) and cortical gyral simplification. (H) Patient 5 (1 year 2 months), showing thin corpus callosum (ARROWHEAD), severe cerebellar hypoplasia (ARROW) with flattening of the pons and hypomyelination. (I) Patient 6-1 (34 years) showing mild cerebellar vermian hypoplasia (ARROW). (J) Patient 7 (1 year) showing cerebellar vermis hypoplasia (ARROW). (K) Patient 81 (6 years 3 months) showing cerebellar vermian hypoplasia (ARROW). (L) Patient 9 showing cerebellar hypoplasia (ARROW) (M) Patient 11-1 showing cerebral atrophy and normal cerebellum.
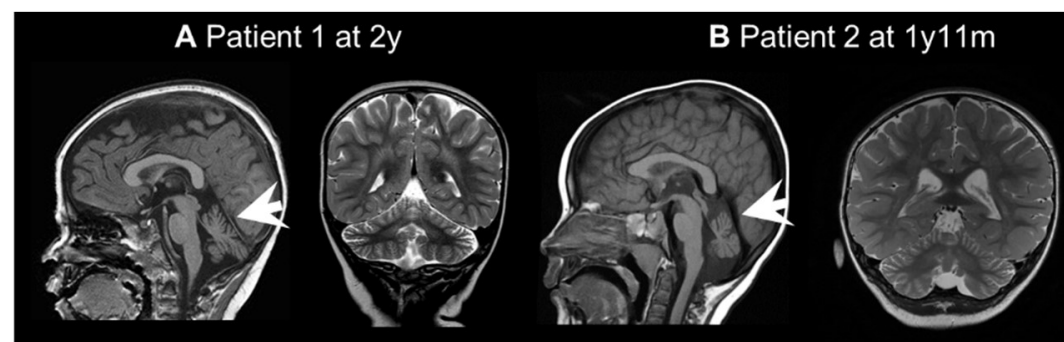

C Patient 3-1 at 1y
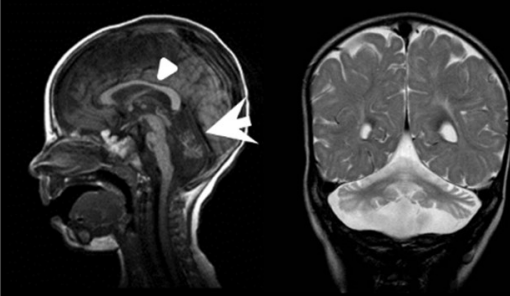

D Patient 3-1 at $2 \mathrm{y} 5 \mathrm{~m}$
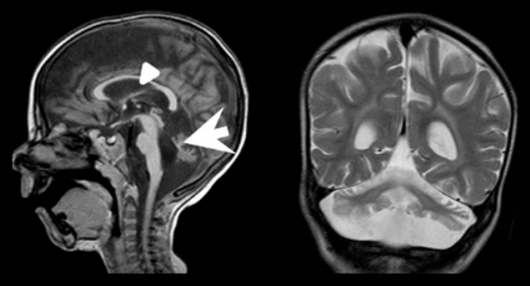

E Patient 3-2 at $11 \mathrm{y} 9 \mathrm{~m}$

F Patient 4 at $1 \mathrm{y}$

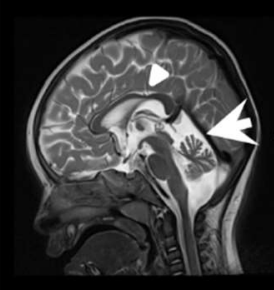

$\mathbf{J}$ Patient 7 at $1 \mathrm{y} \mathbf{K}$ Patient 8-1 at 6y3m
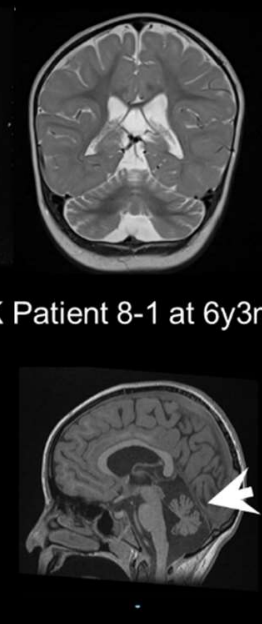

G Patient 4 at $2 \mathrm{y} 5 \mathrm{~m}$

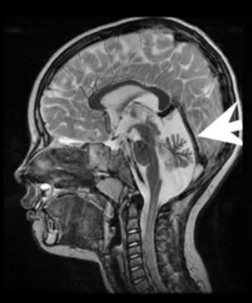

L Patient 9

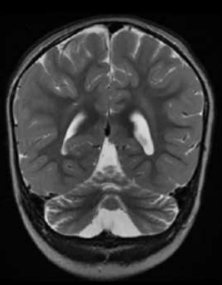

H Patient 5 at $1 \mathrm{y} 2 \mathrm{~m}$

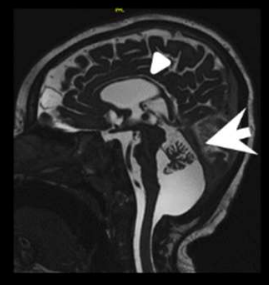

M Patient $11-1$ at $8 y 3 m$

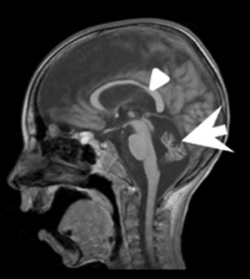

I Patient 6-1 at 34y

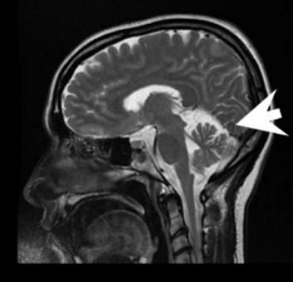

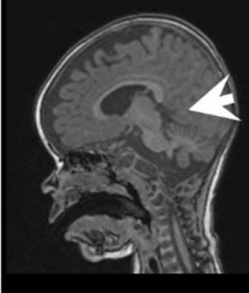
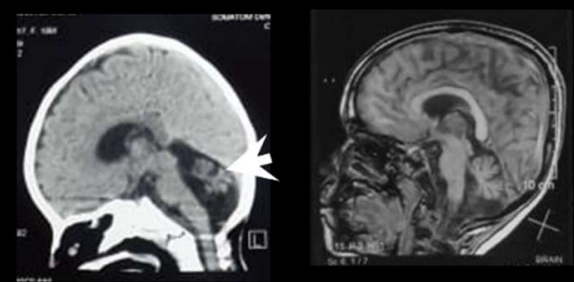
Table 1 Clinical features of patients with biallelic MED27 variants

\begin{tabular}{|l|l|l|l|l|}
\hline Clinical findings & $\begin{array}{l}\text { Severe } \\
(\mathrm{n}=8)\end{array}$ & $\begin{array}{l}\text { Moderate } \\
(\mathrm{n}=5)\end{array}$ & $\begin{array}{l}\text { Family 6 } \\
(\mathrm{n}=2)\end{array}$ & Overall $^{*}$ \\
\hline Gender & & & & $5 \mathrm{M} / 10 \mathrm{~F}$ \\
\hline Intellectual disability & $100 \%(7 / 7)$ & $100 \%(5 / 5)$ & $100 \%(2 / 2)$ & $100 \%(14 / 14)$ \\
\hline Central hypotonia & $100 \%(8 / 8)$ & $80.0 \%(4 / 5)$ & $100 \%(2 / 2)$ & $93.3 \%(14 / 15)$ \\
\hline $\begin{array}{l}\text { Distal limb spasticity/dystonic } \\
\text { movement }\end{array}$ & $100 \%(8 / 8)$ & $60.0 \%(3 / 5)$ & $100 \%(2 / 2)$ & $86.7 \%(13 / 15)$ \\
\hline $\begin{array}{l}\text { Delayed motor/speech } \\
\text { development }\end{array}$ & $100 \%(8 / 8)$ & $100 \%(5 / 5)$ & $0 \%(0 / 2)$ & $86.7 \%(13 / 15)$ \\
\hline Cerebellar hypoplasia & $100 \%(8 / 8)$ & $75.0 \%(3 / 4)$ & $50.0 \%(1 / 2)$ & $85.7 \%(12 / 14)$ \\
\hline Cataracts & $87.5 \%(7 / 8)$ & $20.0 \%(1 / 5)$ & $100 \%(2 / 2)$ & $66.7 \%(10 / 15)$ \\
\hline Epilepsy & $87.5 \%(7 / 8)$ & $40.0 \%(2 / 5)$ & $0 \%(0 / 2)$ & $60.0 \%(9 / 15)$ \\
\hline Feeding issues & $42.8 \%(3 / 7)$ & $60.0 \%(3 / 5)$ & $100 \%(2 / 2)$ & $57.1 \%(8 / 14)$ \\
\hline Microcephaly & $50.0 \%(4 / 8)$ & $0.0 \%(0 / 4)$ & $0 \%(0 / 2)$ & $28.6 \%(4 / 14)$ \\
\hline Developmental regression & $25.0 \%(2 / 8)$ & $20.0 \%(1 / 5)$ & $100 \%(2 / 2)$ & $33.3 \%(5 / 15)$ \\
\hline
\end{tabular}

*Patient 10-2 had dual diagnosis with variants in both MED27 and COG6. Therefore the case is excluded in this summary of MED27associated phenotypes.

Key: M, male; F, female 
Supplementary Table 1 Family pedigrees, facial images of individuals with biallelic MED27 variants and Sanger sequencing data

\begin{tabular}{|l|l|l|l|}
\hline Famil & Pedigree & Facial photos & MED27 variants (Sanger sequencing) \\
\hline 1 & & & \\
\hline
\end{tabular}




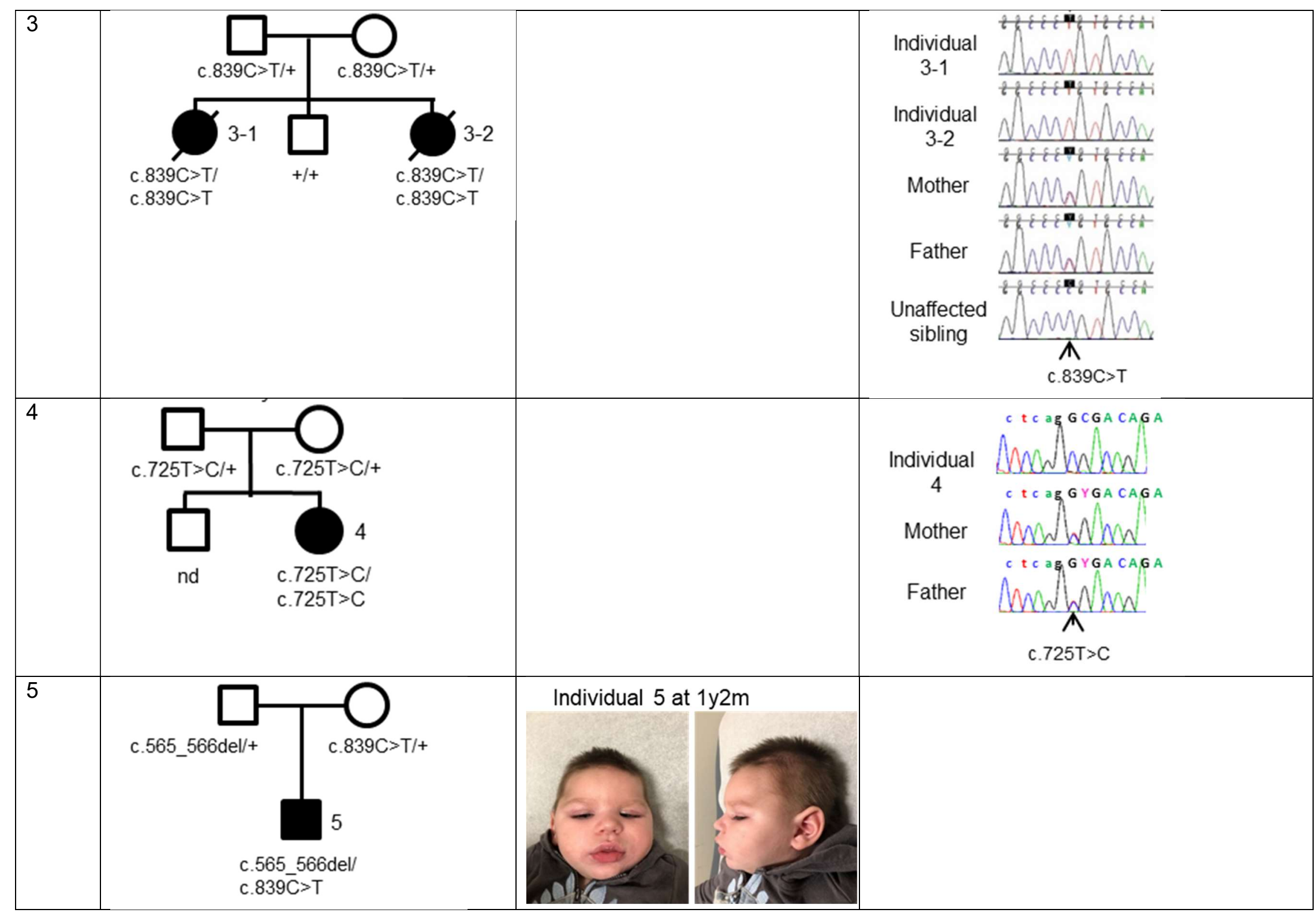




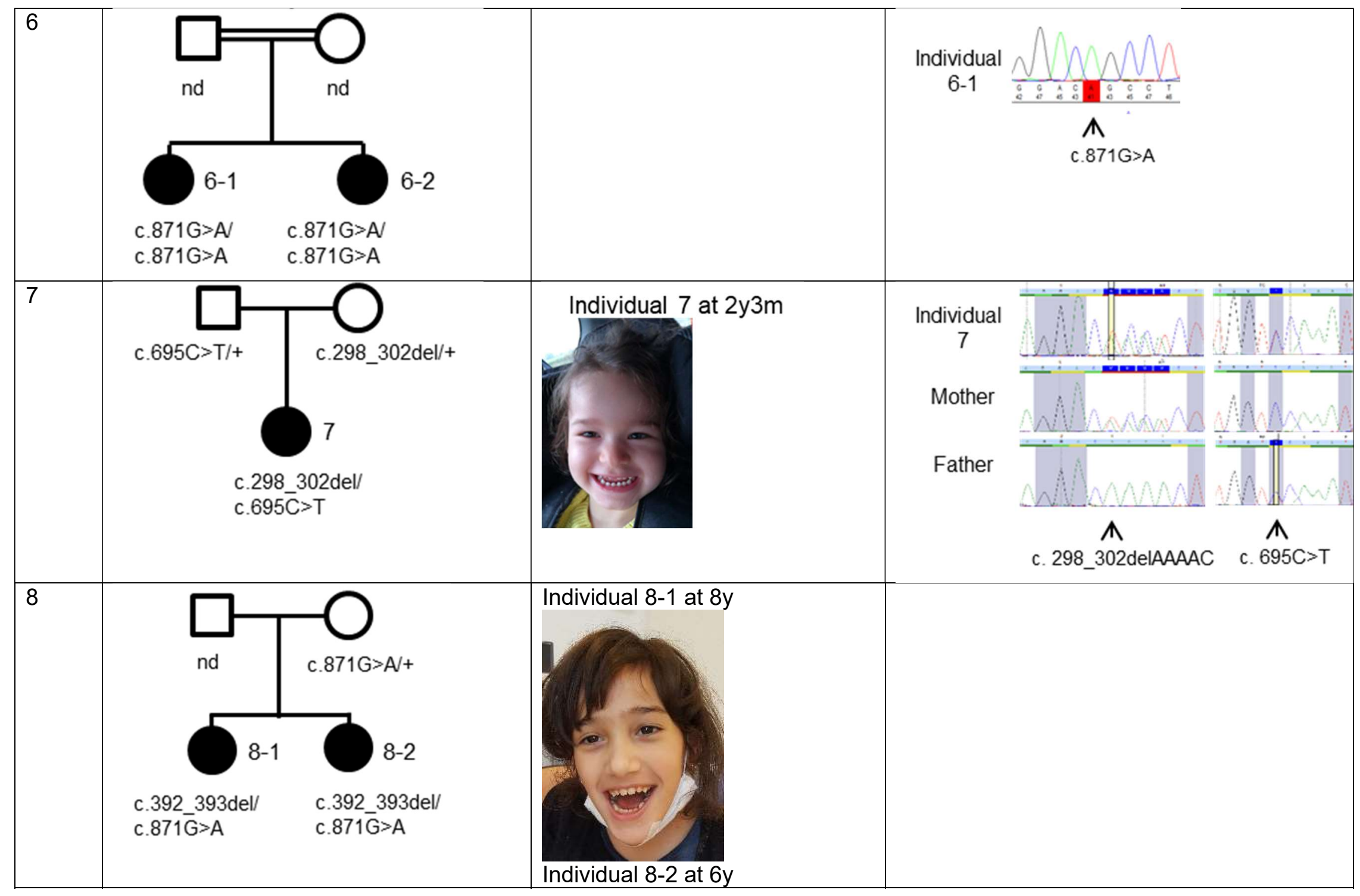




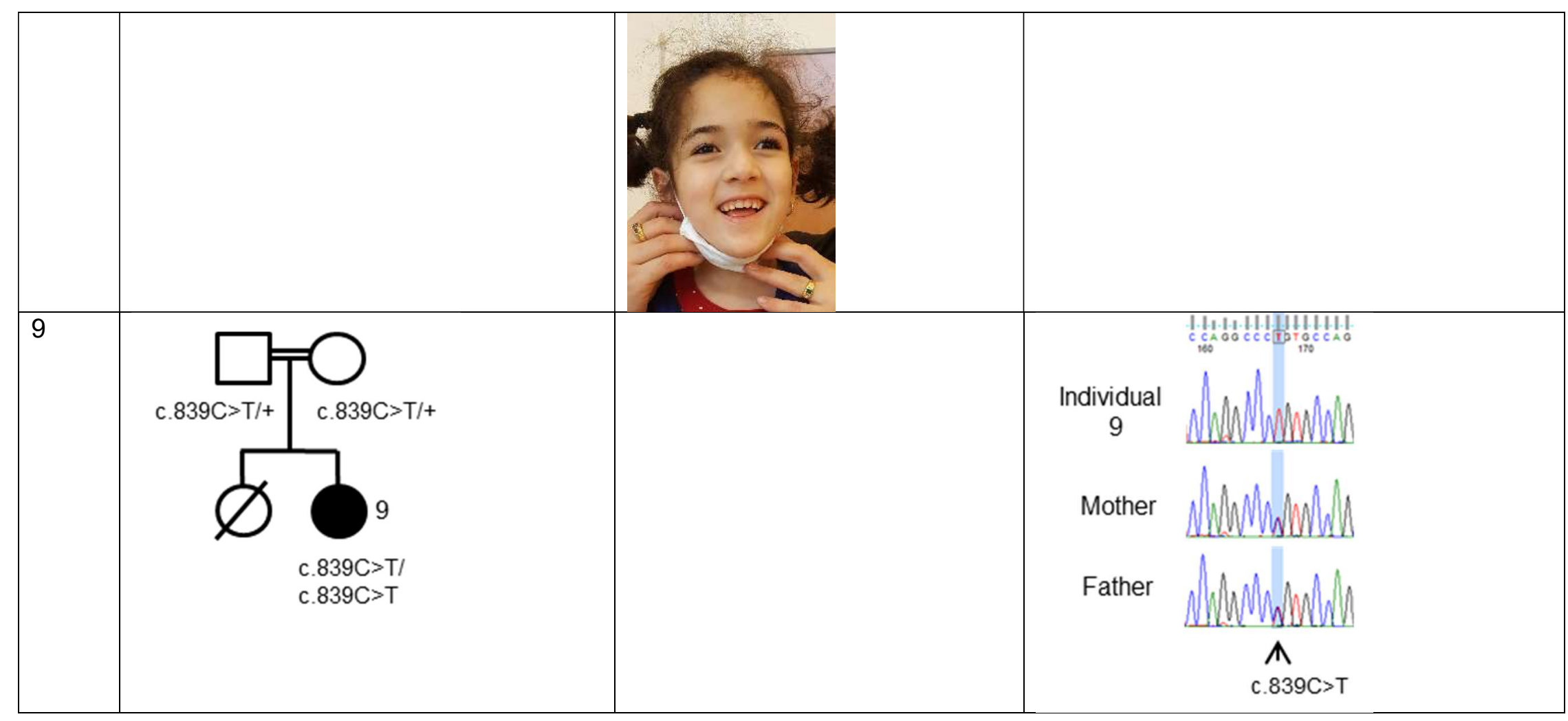




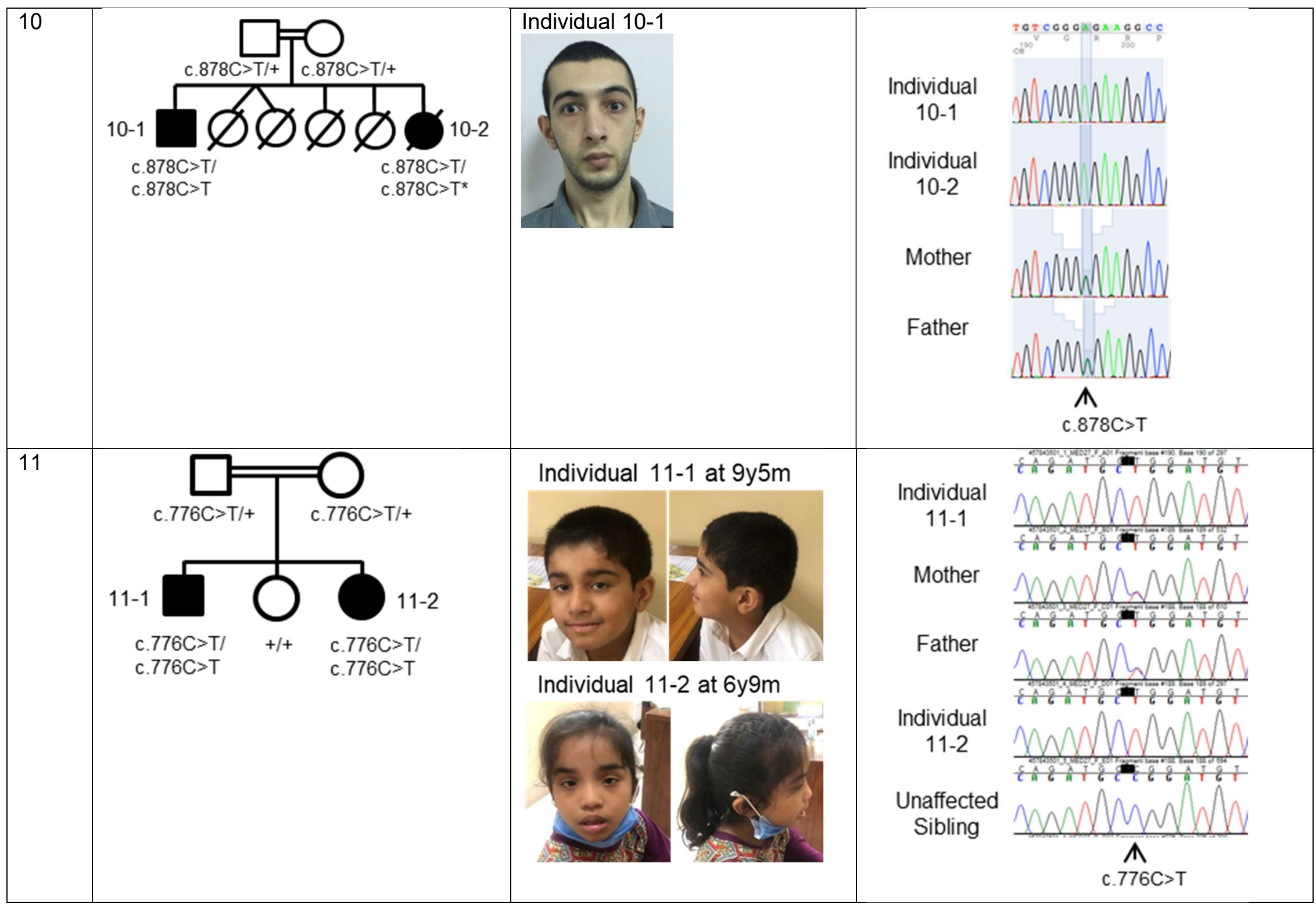

Patients and/or legal guardians have consented for publication of facial images. 
Supplementary Table 2 MED27 Variant characteristics identified in this study

\begin{tabular}{|c|c|c|c|c|c|c|c|c|c|c|}
\hline Family & $\begin{array}{l}\text { Exon/l } \\
\text { ntron }\end{array}$ & cDNA & Protein & $\begin{array}{l}\text { Variant } \\
\text { type }\end{array}$ & $\begin{array}{l}\text { GERP+ } \\
+\quad \text { RS }\end{array}$ & $\begin{array}{l}\text { PolyP } \\
\text { hen2 }\end{array}$ & SIFT & $\begin{array}{l}\text { Mutation } \\
\text { Taster }\end{array}$ & $\begin{array}{l}\text { CADD } \\
\text { Phred score }\end{array}$ & $\begin{array}{l}\text { gnomAD } \\
\text { database }\end{array}$ \\
\hline 1 & Exon 1 & c. $188 \mathrm{~T}>\mathrm{G}$ & p.Val63Gly & Missense & 5.07 & $\mathrm{D}$ & $\mathrm{D}$ & $\mathrm{D}$ & 28.2 & $2 / 245554$ \\
\hline 7 & Exon 2 & c.298_302del & $\begin{array}{l}\text { p.Lys100Serf } \\
s^{*} 4\end{array}$ & Frameshift & NA & NA & NA & NA & NA & 0 \\
\hline 8 & Exon 3 & c.392_393del & $\begin{array}{l}\text { p.GIn131Leu } \\
\mathrm{fs}^{*} 7\end{array}$ & Frameshift & NA & NA & NA & NA & NA & 0 \\
\hline 5 & Exon 4 & c.565_566del & $\begin{array}{l}\text { p.M189Afs*2 } \\
1\end{array}$ & Frameshift & NA & NA & NA & NA & NA & 0 \\
\hline 2 & $\begin{array}{l}\text { Intron } \\
5\end{array}$ & c. $682-2 A>G$ & $\mathrm{~N} / \mathrm{A}$ & Splice site & 5.62 & NA & NA & NA & 34 & $2 / 239080$ \\
\hline 7 & Exon 6 & c. $695 \mathrm{C}>\mathrm{T}$ & p.Ser232Phe & Missense & 5.62 & $\mathrm{P}$ & $\mathrm{D}$ & D & 31 & 0 \\
\hline 4 & Exon 7 & c.725T>C & p.Val242Ala & Missense & 5.52 & $B$ & $\mathrm{D}$ & $\mathrm{D}$ & 26.3 & 0 \\
\hline 1,11 & Exon 7 & c. $776 \mathrm{C}>\mathrm{T}$ & p.Pro259Leu & Missense & 5.52 & $\mathrm{D}$ & $\mathrm{D}$ & $\mathrm{D}$ & 34 & 0 \\
\hline $3,5,9$ & Exon 8 & c.839C>T & p.Pro280Leu & Missense & 5.3 & $P$ & $\mathrm{D}$ & $\mathrm{D}$ & 34 & $14 / 241660$ \\
\hline $2,6,8$ & Exon 8 & c. $871 \mathrm{G}>\mathrm{A}$ & p.Gly291Ser & Missense & 5.3 & $\mathrm{D}$ & $\mathrm{D}$ & $\mathrm{D}$ & 27.5 & $3 / 235830$ \\
\hline 10 & Exon 8 & c. $878 \mathrm{C}>\mathrm{T}$ & p.Pro293Leu & Missense & 5.46 & $D$ & $\mathrm{D}$ & $\mathrm{D}$ & 29.9 & 0 \\
\hline
\end{tabular}

Reference sequence: NM_004269.3; D: probably damaging; P: possibly damaging; B: benign 
Supplementary Table 3 Summary of clinical features in patients with biallelic MED27 variants.

\begin{tabular}{|c|c|c|c|c|c|c|c|c|}
\hline Individual & 1 & 2 & 3-1 & 3-2 & 4 & 5 & 6-1 & $6-2$ \\
\hline $\begin{array}{l}\text { Disease } \\
\text { severity }\end{array}$ & Moderate & Severe & Severe & Severe & Severe & Severe & Family 6 & Family 6 \\
\hline Gender & Male & Male & Female & Female & Female & Male & Female & Female \\
\hline Ethnicity & Hispanic & $\begin{array}{l}\text { Western } \\
\text { European }\end{array}$ & Finnish & Finnish & Turkish/Syrian & \begin{tabular}{|l|} 
European, \\
French Canadian
\end{tabular} & Kuwaiti & Kuwaiti \\
\hline Consanguinity & No & No & No & No & No & No & Yes & Yes \\
\hline Birth history & Normal & Normal & Normal & Normal & Normal & Normal & Normal & Normal \\
\hline $\begin{array}{l}\text { Age at } \\
\text { measurement }\end{array}$ & $10 y 7 m$ & $5 y 10 m$ & $\begin{array}{l}11 \mathrm{y}, \text { (passed at } \\
13 \mathrm{y})\end{array}$ & $\begin{array}{l}8 \mathrm{~m} \text { (passed at } \\
5 \mathrm{y})\end{array}$ & $2 \mathrm{y} 11 \mathrm{~m}$ & $20 \mathrm{~m}$ & $36 y$ & $42 y$ \\
\hline Height & 23\%ile (-0.8SD) & $52 \%$ ile (-0.1SD) & $<1 \%$ ile (-3SD) & 20\%ile (-0.84SD) & $49 \%$ ile $(-0.03 S D)$ & $35 \%$ ile (-0.39SD) & NA & $<1 \%$ ile $(-2.8 \mathrm{SD})$ \\
\hline Weight & 14\%ile (-1.1SD) & 12\%ile (-1.3SD) & $43 \%$ ile (-0.18SD) & $18 \%$ ile $(-0.92 S D)$ & $27 \%$ ile $(-0.61 S D)$ & $33 \%$ ile $(-0.44 S D)$ & NA & 23\%ile (-0.74SD \\
\hline FOC & $2 \%$ ile (-1.99SD) & $\begin{array}{l}<1 \% \text { ile (-3.3SD) } \\
\text { (at 33m) }\end{array}$ & $<1 \%$ ile (-5SD) & $<1 \%$ ile (-3.5SD) & $5 \%$ ile (-1.61SD) & $<1 \%$ ile (-4.6SD) & Normocephalic & Normocephalic \\
\hline Microcephaly & - & + & + & + & - & + & - & - \\
\hline Feeding issues & $\begin{array}{l}\text { Difficult } \\
\text { swallowing }\end{array}$ & $\begin{array}{l}\text { Swallowing } \\
\text { issue, G-tube } \\
\text { placement }\end{array}$ & - & - & $\begin{array}{l}\text { severe } \\
\text { swallowing issue }\end{array}$ & Dysphagia & $\begin{array}{l}\text { Occasional } \\
\text { choking }\end{array}$ & $\begin{array}{l}\text { Occasional } \\
\text { choking }\end{array}$ \\
\hline $\begin{array}{l}\text { Development } \\
\text { assessment }\end{array}$ & \begin{tabular}{|l|} 
Chronological \\
age $10.8 \mathrm{y}$, \\
intelligence $<4 \mathrm{y}$, \\
expressive \\
language $23 \mathrm{~m}$, \\
receptive \\
language $3 y$, fine \\
motor $3.5 y$ \\
visual perceptual \\
ability $4 \mathrm{y}$
\end{tabular} & NA & NA & NA & $\begin{array}{l}\text { NA, felt to be } 6 \mathrm{~m} \\
\text { at chronological } \\
\text { age of } 6 y\end{array}$ & NA & NA & NA \\
\hline Motor delay & $\begin{array}{l}+, \text { delayed, able } \\
\text { to walk }\end{array}$ & $\begin{array}{l}+ \text {, cannot } \\
\text { sit/walk }\end{array}$ & $\begin{array}{l}+ \text {, cannot } \\
\text { sit/walk }\end{array}$ & $\begin{array}{l}+, \text { achieved } \\
\text { walking but } \\
\text { regressed and } \\
\text { lost ability to } \\
\text { move }\end{array}$ & $\begin{array}{l}+, \text { sit with } \\
\text { support, cannot } \\
\text { walk }\end{array}$ & $\begin{array}{l}+, \text { poor head } \\
\text { control, cannot } \\
\text { sit/walk }\end{array}$ & - & - \\
\hline Language delay & $\begin{array}{l}+, \text { delayed, } 10 \\
\text { words at } 40 \mathrm{~m}\end{array}$ & + , non-verbal & + , non-verbal &,+ non-verbal &,+ non-verbal & $\begin{array}{l}+, \text { non-verbal } \\
\text { (early) }\end{array}$ & $\begin{array}{l}- \text {, progressive } \\
\text { dysarthria since } \\
\text { age } 8\end{array}$ & $\begin{array}{l}\text {-, progressive } \\
\text { dysarthria since } \\
\text { age } 5\end{array}$ \\
\hline \begin{tabular}{|l|}
$\begin{array}{l}\text { Intellectual } \\
\text { disability }\end{array}$ \\
\end{tabular} & Moderate & Profound & Severe & Severe & Profound & NA (early) & Moderate & Moderate \\
\hline
\end{tabular}




\begin{tabular}{|c|c|c|c|c|c|c|c|c|}
\hline $\begin{array}{l}\text { Developmental } \\
\text { regression }\end{array}$ & - & $\begin{array}{l}+, \text { at } 7 y, \text { motor } \\
\text { function is } \\
\text { worsening }\end{array}$ & $\begin{array}{l}+, \text { onset around } \\
6 y\end{array}$ & - & - & - & + & + \\
\hline \begin{tabular}{|l|} 
Central \\
hypotonia
\end{tabular} & - & + & + & + & + & + & Mild & Mild \\
\hline Distal spasticity & - & + & + & + & + & + & + & + \\
\hline $\begin{array}{l}\text { Dystonic } \\
\text { movement }\end{array}$ & -, Unsteady gait & $\begin{array}{l}+, \text { tongue } \\
\text { protrusion }\end{array}$ & + & + & + , hands & $\begin{array}{l}+, \text { tongue } \\
\text { protrusion }\end{array}$ & $\begin{array}{l}+, \text { tongue, } \\
\text { mandibular, } \\
\text { dysarthria, } \\
\text { posture }\end{array}$ & $\begin{array}{l}+, \text { tongue, } \\
\text { mandibular, } \\
\text { dysarthria, } \\
\text { posture }\end{array}$ \\
\hline Epilepsy & $\begin{array}{l}- \text {-, seizure like } \\
\text { activity in } \\
\text { infancy, normal } \\
\text { EEG }\end{array}$ & + , onset $2 y$ & + , onset $3 y$ & + , onset $2 \mathrm{y}$ & + , onset $2-3 y$ & $\begin{array}{l}+, \text { onset } 8 \mathrm{~m}, \\
\text { abnormal EEG, } \\
\text { consistent with } \\
\text { modified } \\
\text { hypsarrhythmia }\end{array}$ & - & - \\
\hline $\begin{array}{l}\text { History of Drug- } \\
\text { resistant } \\
\text { epilepsy }\end{array}$ & NA & - & $\begin{array}{l}+(\text { at } 6 \text { y then } \\
\text { became seizure } \\
\text { free on AEDs at } \\
11 y)\end{array}$ & - & + & + & NA & NA \\
\hline $\begin{array}{l}\text { Seizure type(s) } \\
\text { and frequency }\end{array}$ & NA & $\begin{array}{l}\text { Generalized } \\
\text { tonic-clonic } \\
\text { seizure }\end{array}$ & $\mathrm{N} / \mathrm{A}$ & $\mathrm{N} / \mathrm{A}$ & $\begin{array}{l}\text { Myoclonic during } \\
\text { sleep, atypical } \\
\text { absences during } \\
\text { daytime; multiple } \\
\text { daily. }\end{array}$ & \begin{tabular}{|l|} 
Focal motor \\
(tonic), absence, \\
epileptic \\
(infantile) \\
spasms; multiple \\
daily.
\end{tabular} & NA & NA \\
\hline AEDs & NA & $\begin{array}{l}\text { GBP and low } \\
\text { dose LEV }\end{array}$ & $\begin{array}{l}\text { VPA, TPM and } \\
\text { PB }\end{array}$ & VPA & $\mathrm{N} / \mathrm{A}$ & $\begin{array}{l}\text { Steroids, ACTH, } \\
\text { Vigabatrin, LEV } \\
\text { and CBZ }\end{array}$ & NA & NA \\
\hline $\begin{array}{l}\text { Brain MRI } \\
\text { cerebellar } \\
\text { atrophy } \\
\end{array}$ & mild & + & + & ( &,+ progressive & + & mild & - \\
\hline $\begin{array}{l}\text { Brain MRI } \\
\text { others }\end{array}$ & - & $\begin{array}{l}\text { progression of } \\
\text { diffuse cerebral } \\
\text { atrophy and } \\
\text { progression of } \\
\text { abnormal signal } \\
\text { and atrophy in } \\
\text { basal ganglia }\end{array}$ & $\begin{array}{l}\text { cerebral atrophy, } \\
\text { thin corpus } \\
\text { callosum }\end{array}$ & $\begin{array}{l}\text { cerebral atrophy, } \\
\text { thin corpus } \\
\text { callosum }\end{array}$ & $\begin{array}{l}\text { cortical gyral } \\
\text { simplification }\end{array}$ & \begin{tabular}{|l|} 
hypomyelination \\
with a thin \\
corpus callosum, \\
progressive ex \\
vacuo \\
ventriculomegaly
\end{tabular} & - & - \\
\hline Cataracts & - & $\begin{array}{l}+, \text { left mature } \\
\text { cataract, right } \\
\text { incomplete } \\
\text { cataract }\end{array}$ & $\begin{array}{l}+, \text { congenital, } \\
\text { operated at } 7 y, \\
\text { type NA }\end{array}$ & $\begin{array}{l}+, \text { congenital, } \\
\text { operated at } 5 \mathrm{~m} \text {, } \\
\text { type NA }\end{array}$ & + , mature & $\begin{array}{l}+, \text { developed at } \\
23 \mathrm{~m} \text {, type not } \\
\text { specified }\end{array}$ & + , mature & + , mature \\
\hline $\begin{array}{l}\text { Dysmorphic } \\
\text { features }\end{array}$ & $\begin{array}{l}\text { Large cupped } \\
\text { ears with }\end{array}$ & $\begin{array}{l}\text { Prominent } \\
\text { eyebrows }\end{array}$ & - & - & $\begin{array}{l}\text { narrow forehead, } \\
\text { frontal upsweep }\end{array}$ & $\begin{array}{l}\text { Large ears, } \\
\text { slightly upturned }\end{array}$ & - & - \\
\hline
\end{tabular}




\begin{tabular}{|c|c|c|c|c|c|c|c|c|}
\hline & $\begin{array}{l}\text { thickened } \\
\text { helices, long } \\
\text { eyelashes, } \\
\text { frontal bossing, } \\
\text { upswept frontal } \\
\text { hair }\end{array}$ & & & & $\begin{array}{l}\text { of hair, } \\
\text { synophrys, } \\
\text { highly arched } \\
\text { broad eyebrows, } \\
\text { large eyes, blue } \\
\text { sclerae, } \\
\text { prominent nasal } \\
\text { bridge, } \\
\text { anteverted } \\
\text { nares, } \\
\text { exaggerated } \\
\text { cupid bow, } \\
\text { widely spaced } \\
\text { teeth, long } \\
\text { eyelashes, long } \\
\text { hyperextensible } \\
\text { and broad } \\
\text { fingers, } \\
\text { hypertrichosis }\end{array}$ & $\begin{array}{l}\text { nose, long } \\
\text { eyelashes, full } \\
\text { lips }\end{array}$ & & \\
\hline Other issues & $\begin{array}{l}\text { Mild obstructive } \\
\text { sleep apnea; } \\
\text { Significant } \\
\text { drooling, } \\
\text { behavioral } \\
\text { concerns; Dental } \\
\text { concern }\end{array}$ & $\begin{array}{l}\text { Born with loud } \\
\text { breathing and } \\
\text { diagnosed with } \\
\text { laryngomalacia } \\
\text { as infant }\end{array}$ & $\begin{array}{l}\text { Peripheral } \\
\text { neuropathy both } \\
\text { in lower and } \\
\text { upper limbs }\end{array}$ & $\mathrm{N} / \mathrm{A}$ & Drooling & \begin{tabular}{|l|} 
Severe central \\
sleep apnea, \\
moderate \\
obstructive sleep \\
apnea, \\
laryngomalacia, \\
milk protein \\
allergy, \\
constipation, \\
bilateral hearing \\
loss
\end{tabular} & $\begin{array}{l}\text { Urinary urgency } \\
\text { with frequent } \\
\text { episodes of } \\
\text { incontinence }\end{array}$ & $\begin{array}{l}\text { Urinary urgency } \\
\text { with frequent } \\
\text { episodes of } \\
\text { incontinence }\end{array}$ \\
\hline $\begin{array}{l}\text { MED27 } \\
\text { (NM_004269.3) }\end{array}$ & $\begin{array}{l}\text { c.776C>T } \\
\text { (p.Pro259Leu) } \\
\text { presumed } \\
\text { paternal; } \\
\text { c.188T>G } \\
\text { (p.Val63Gly) } \\
\text { maternal } \\
\end{array}$ & $\begin{array}{l}\text { c.682-2A>G } \\
\text { paternal; } \\
\text { c.871G>A } \\
\text { (p.Gly291Ser) } \\
\text { maternal }\end{array}$ & $\begin{array}{l}\text { Homozygous } \\
\text { c.839C>T } \\
\text { (p.Pro280Leu) }\end{array}$ & $\begin{array}{l}\text { Homozygous } \\
\text { c.839C>T } \\
\text { (p.Pro280Leu) }\end{array}$ & $\begin{array}{l}\text { Homozygous } \\
\text { c.725T>C } \\
\text { (p.Val242Ala) }\end{array}$ & $\begin{array}{l}\text { c.565_566del(p. } \\
\text { Met189Alafs*21) } \\
\text { paternal; } \\
\text { c.839C>T } \\
\text { (p.Pro280Leu) } \\
\text { maternal }\end{array}$ & $\begin{array}{l}\text { Homozygous } \\
\text { c.871G>A } \\
\text { (p.Gly291Ser) }\end{array}$ & $\begin{array}{l}\text { Homozygous } \\
\text { c.871G>A } \\
\text { (p.Gly291Ser) }\end{array}$ \\
\hline $\begin{array}{l}\text { Additional } \\
\text { diagnosis }\end{array}$ & & & & & & & & \\
\hline
\end{tabular}




\begin{tabular}{|c|c|c|c|c|c|c|c|c|c|}
\hline Individual & 7 & $8-1$ & $8-2$ & 9 & $10-1$ & $10-2^{*}$ & $11-1$ & $11-2$ & Total \\
\hline $\begin{array}{l}\text { Disease } \\
\text { severity }\end{array}$ & Severe & Severe & Severe & Moderate & Moderate & NA & Moderate & Moderate & $\begin{array}{l}8 \text { severe; } 5 \\
\text { moderate }\end{array}$ \\
\hline Gender & Female & Female & Female & Female & Male & Female & Male & Female & $5 \mathrm{M} / 11 \mathrm{~F}$ \\
\hline Ethnicity & $\begin{array}{l}\text { North-western } \\
\text { European }\end{array}$ & Algerian & Algerian & Iraqi & Turkish & Turkish & Pakistani & Pakistani & \\
\hline $\begin{array}{l}\text { Consanguinit } \\
y\end{array}$ & No & Yes & Yes & Yes & Yes & Yes & Yes & Yes & \\
\hline Birth history & Normal & Normal & Normal & Normal & Normal & $\begin{array}{l}\text { Polyhydramnio } \\
\text { s, SGA, } \\
\text { respiratory } \\
\text { distress }\end{array}$ & Normal & Preterm & \\
\hline $\begin{array}{l}\text { Age at } \\
\text { measurement }\end{array}$ & $2 y 3 m$ & $7 y 4 m$ & $5 y 11 m$ & $10 m$ & $20 y$ & $\begin{array}{l}16 \mathrm{~d} \text {, (passed } \\
\text { at } 3 \mathrm{~m})\end{array}$ & $9 y 5 m$ & $6 y r$ 9mo & \\
\hline Height & $\begin{array}{l}2 \% \text { ile (- } \\
2.04 \text { SD) }\end{array}$ & $\begin{array}{l}\text { 18\%ile (- } \\
0.3 \mathrm{SD})\end{array}$ & $\begin{array}{l}20 \% \text { ile (- } \\
0.82 \text { SD) }\end{array}$ & NA & $\begin{array}{l}25 \% \text { ile (- } \\
0.67 S D)\end{array}$ & $50 \%$ ile (0SD) & $\begin{array}{l}44 \% \text { ile (- } \\
0.16 \text { SD) }\end{array}$ & $\begin{array}{l}21 \% \text { ile (- } \\
0.82 \text { SD) }\end{array}$ & \\
\hline Weight & \begin{tabular}{|l}
$41 \%$ ile (- \\
$0.24 S D)$
\end{tabular} & $\begin{array}{l}14 \% \text { ile (- } \\
0.65 S D)\end{array}$ & $\begin{array}{l}29 \% \text { ile (- } \\
0.57 \text { SD) }\end{array}$ & $\begin{array}{l}>99 \% \text { ile } \\
(>=+3.0 S D)\end{array}$ & $\begin{array}{l}3 \% \text { ile (- } \\
1.88 \mathrm{SD}) \\
\end{array}$ & $\begin{array}{l}25 \% \text { ile (- } \\
0.67 S D)\end{array}$ & $\begin{array}{l}\begin{array}{l}75 \% \text { ile } \\
(+0.67 S D)\end{array} \\
\end{array}$ & $\begin{array}{l}25 \% \text { ile (- } \\
0.68 S D)\end{array}$ & \\
\hline FOC & $\begin{array}{l}18 \% \text { ile (- } \\
0.92 \text { SD) }\end{array}$ & $\begin{array}{l}\text { 12\%ile (- } \\
1.16 \mathrm{SD}) \\
\end{array}$ & $\begin{array}{l}\text { 13\%ile (- } \\
1.12 \text { SD) } \\
\end{array}$ & NA & \begin{tabular}{|l|}
$<<\%$ ile, $<-$ \\
$1.88 S D$
\end{tabular} & \begin{tabular}{|l|}
$<<3 \%$ ile, $<-$ \\
$1.88 S D$
\end{tabular} & $\begin{array}{l}53 \% \text { ile } \\
(+0.08 \mathrm{SD})\end{array}$ & $\begin{array}{l}27 \% \text { ile (- } \\
0.61 \text { SD) }\end{array}$ & $4 / 14$ \\
\hline Microcephaly & - & - & - & - & - & - & - & - & $4 / 14$ \\
\hline $\begin{array}{l}\text { Feeding } \\
\text { issues }\end{array}$ & NA & - & - & + & - & + & - & Mild & $8 / 14$ \\
\hline $\begin{array}{l}\text { Development } \\
\text { assessment }\end{array}$ & $\begin{array}{l}\text { Bailey scale: } \\
\text { chronological } \\
\text { age } 16 \mathrm{~m}, \\
\text { cognition } 7 \mathrm{~m}\end{array}$ & NA & NA & NA & $\begin{array}{l}\text { NA, felt to be } \\
5-6 y \text { level at } \\
\text { chronological } \\
\text { age of } 20 y\end{array}$ & NA & $\begin{array}{l}\text { Protage guide: } \\
\text { Chronological } \\
\text { age } 9.5 \mathrm{y}, \\
\text { Cognition } \\
66.4 \mathrm{~m}, \\
\text { Socialization } \\
57.8 \mathrm{~m} \text {, Self- } \\
\text { help } 61.5 \mathrm{~m} \text {, } \\
\text { Motor } 61.6 \mathrm{~m} \text {, } \\
\text { Language } 48 \mathrm{~m}\end{array}$ & $\begin{array}{l}\text { Protage guide: } \\
\text { Chronological } \\
\text { age } 7.1 \mathrm{y}, \\
\text { Cognition } 67 \mathrm{~m}, \\
\text { Socialization } \\
59 \mathrm{~m}, \text { Self-help } \\
68 \mathrm{~m}, \text { Motor } \\
66 \mathrm{~m}, \\
\text { Language } 59 \mathrm{~m}\end{array}$ & \\
\hline Motor delay & $\begin{array}{l}+, \text { cannot } \\
\text { sit/walk }\end{array}$ & + & + , cruising & \begin{tabular}{|l|}
+ , walk with \\
support
\end{tabular} &,+ able to walk & NA & $\begin{array}{l}+, \text { delayed, } \\
\text { able to walk }\end{array}$ & $\begin{array}{l}+, \text { delayed, } \\
\text { able to walk }\end{array}$ & $13 / 15$ \\
\hline $\begin{array}{l}\text { Language } \\
\text { delay }\end{array}$ & + , non-verbal & + , delayed & + , non-verbal & $\begin{array}{l}+, \text { delayed, one } \\
\text { word at } 22 m\end{array}$ & $\begin{array}{l}+, \text { delayed, } \\
\text { able to read }\end{array}$ & NA &,+ delayed &,+ delayed & $13 / 15$ \\
\hline $\begin{array}{l}\text { Intellectual } \\
\text { disability }\end{array}$ & Severe & Profound & Profound & Moderate & Moderate & $\mathrm{N} / \mathrm{A}$ & Moderate & Mild & $14 / 14$ \\
\hline
\end{tabular}




\begin{tabular}{|c|c|c|c|c|c|c|c|c|c|}
\hline $\begin{array}{l}\text { Developmenta } \\
\text { I regression }\end{array}$ & - & - & - & - & + & NA & |- & |- & $5 / 15$ \\
\hline $\begin{array}{l}\text { Central } \\
\text { hypotonia }\end{array}$ & + & + & + & + & + & + & Mild & Mild & $14 / 15$ \\
\hline $\begin{array}{l}\text { Distal } \\
\text { spasticity }\end{array}$ & + & + & + & + & - & - & + & mild & $13 / 15$ \\
\hline $\begin{array}{l}\text { Dystonic } \\
\text { movement }\end{array}$ & $\begin{array}{l}+ \text {, tongue } \\
\text { protrusion, } \\
\text { stereotypical } \\
\text { movements }\end{array}$ & + & + & + & - & NA & $\begin{array}{l}+, \text { tongue } \\
\text { fasciculations }\end{array}$ & $\begin{array}{l}+, \text { tongue } \\
\text { fasciculations }\end{array}$ & $13 / 15$ \\
\hline Epilepsy & $\begin{array}{l}\text {-, disturbed } \\
\text { EEG }\end{array}$ & $\begin{array}{l}+, \text { onset } 5 y, \\
\text { abnormal EEG }\end{array}$ & $\begin{array}{l}+, \text { onset 5y, } \\
\text { abnormal EEG }\end{array}$ & $\begin{array}{l}+, \text { onset at } \\
18 m ; \text { normal } \\
\text { EEG }\end{array}$ & - & - &,+ onset at $20 \mathrm{~d}$ & - & $9 / 15$ \\
\hline $\begin{array}{l}\text { History of } \\
\text { Drug-resistant } \\
\text { epilepsy }\end{array}$ & NA & - & - & $\begin{array}{l}\text { Unable to } \\
\text { assess }\end{array}$ & NA & NA & - & NA & $3 / 15$ \\
\hline $\begin{array}{l}\text { Seizure } \\
\text { type(s) and } \\
\text { frequency }\end{array}$ & NA & $\begin{array}{l}\text { Hemifacial } \\
\text { clonic seizures; } \\
\text { none while on } \\
\text { AEDs }\end{array}$ & $\begin{array}{l}\text { Hemifacial } \\
\text { clonic; none } \\
\text { while on AEDs }\end{array}$ & \begin{tabular}{|l} 
Focal motor \\
with impaired \\
awareness
\end{tabular} & NA & NA & $\begin{array}{l}\text { Atonic and } \\
\text { right- sided } \\
\text { focal; once } \\
\text { every week till } \\
6 Y \text { when he } \\
\text { experienced a } \\
\text { prolonged } \\
\text { GTC; Last } \\
\text { seizure was } 7 Y \\
\text { on AEDs } \\
\end{array}$ & NA & \\
\hline Current AEDs & NA & $\begin{array}{l}\text { VPA and CLB } \\
\text { effective; LEV } \\
\text { previously } \\
\text { used and only } \\
\text { partially } \\
\text { effective }\end{array}$ & $\begin{array}{l}\text { VPA and CLB } \\
\text { effective; LEV } \\
\text { previously } \\
\text { used and only } \\
\text { partially } \\
\text { effective }\end{array}$ & none & NA & NA & $\begin{array}{l}\text { VPA and LEV } \\
\text { for last 3yrs } \\
\text { (effective) }\end{array}$ & NA & \\
\hline $\begin{array}{l}\text { Brain MRI } \\
\text { cerebellar } \\
\text { atrophy }\end{array}$ & mild & + & + & + & mild & mild & - & NA & $12 / 14$ \\
\hline $\begin{array}{l}\text { Brain MRI } \\
\text { others }\end{array}$ & - & - & - & - & - & - & $\begin{array}{l}\text { cerebral } \\
\text { atrophy with } \\
\text { ischemic } \\
\text { demyelination } \\
\text { in parietal and } \\
\text { occipital white } \\
\text { matter }\end{array}$ & - & \\
\hline Cataracts & - & + , congenital & + , congenital & - & $\begin{array}{l}+, \text { posterior } \\
\text { cataracts }\end{array}$ & $\begin{array}{l}+, \text { posterior } \\
\text { cataracts }\end{array}$ & - & - & $10 / 15$ \\
\hline
\end{tabular}




\begin{tabular}{|c|c|c|c|c|c|c|c|c|}
\hline $\begin{array}{l}\text { Dysmorphic } \\
\text { features }\end{array}$ & \begin{tabular}{|l|} 
frontal bossing, \\
sparse medial \\
eyebrow, wide \\
nasal bridge, \\
hypoplasia of \\
the primary \\
teeth, Deep \\
palmar creases
\end{tabular} & $\begin{array}{l}\text { no (long } \\
\text { narrow face) }\end{array}$ & - & - & micrognathia & |- & |- & $\begin{array}{l}\text { Hypertelorism, } \\
\text { flat nasal } \\
\text { bridge, low set } \\
\text { ears, broad } \\
\text { nose, } \\
\text { convergent } \\
\text { squint }\end{array}$ \\
\hline Other issues & Drooling & Drooling & Drooling & NA & $\begin{array}{l}\text { Knee and wrist } \\
\text { contractures, } \\
\text { dysmetria }\end{array}$ & $\begin{array}{l}\text { Hand and feet } \\
\text { contractures }\end{array}$ & $\begin{array}{l}\text { Micropenis } \\
\text { with normal } \\
\text { testosterone } \\
\text { levels, mild } \\
\text { drooling }\end{array}$ & Drooling \\
\hline $\begin{array}{l}\text { MED27 } \\
\text { (NM_004269.3 }\end{array}$ & \begin{tabular}{|l|} 
c.695C>T \\
(p.Ser232Phe) \\
paternal; \\
c.298_302del \\
(p.Lys100Serfs \\
*4) maternal \\
\end{tabular} & $\begin{array}{l}\text { c.871G>A } \\
\text { (p.Gly291Ser) } \\
\text { maternal; } \\
\text { c.392_393del( } \\
\text { p.GIn131Leufs } \\
\text { Ter7) } \\
\text { presumed } \\
\text { paternal }\end{array}$ & $\begin{array}{l}\text { c.871G>A } \\
\text { (p.Gly291Ser) } \\
\text { maternal; } \\
\text { c.392_393del( } \\
\text { p.GIn131Leufs } \\
\text { Ter7) } \\
\text { presumed } \\
\text { paternal }\end{array}$ & $\begin{array}{l}\text { Homozygous } \\
\text { c.839C>T } \\
\text { (p.Pro280Leu) }\end{array}$ & $\begin{array}{l}\text { Homozygous } \\
\text { c.878C>T: } \\
\text { p.Pro293Leu; } \\
\text { both parents } \\
\text { are } \\
\text { heterozygous }\end{array}$ & $\begin{array}{l}\text { Homozygous } \\
\text { c.878C>T: } \\
\text { p.Pro293Leu; } \\
\text { both parents } \\
\text { are } \\
\text { heterozygous }\end{array}$ & $\begin{array}{l}\text { Homozygous } \\
\text { c.776C>T, } \\
\text { p.Pro259Leu }\end{array}$ & $\begin{array}{l}\text { Homozygous } \\
\text { c.776C>T, } \\
\text { p.Pro259Leu }\end{array}$ \\
\hline $\begin{array}{l}\text { Additional } \\
\text { diagnosis }\end{array}$ & & & & & & $\begin{array}{l}\text { Homozygous } \\
\text { COG6 } \\
\text { c.726del } \\
\text { (p.Cys242Trpfs } \\
* 7)\end{array}$ & & \\
\hline
\end{tabular}

*Patient has dual diagnosis with variants in both MED27 and COG6, not counted towards phenotype summary in Table 1

AED: antiepileptic drug; CBZ: carbamazepine; CLB: clobazam; EMG: electroneuromyography; GBP: gabapentin; LEV: levetiracetam; NA: not available; NCS: nerve conduction studies; PB: phenobarbital; SSEP: somato-sensory evoked potentials; TPM: topiramate; VPA: valproate 


\section{Supplementary Table 4 Summary of Mediator subunits known to be associated with human diseases}

\begin{tabular}{|l|l|l|l|l|}
\hline Gene & Module & Inheritance & Disease & Phenotype description \\
\hline MED12 & Kinase & XL & $\begin{array}{l}\text { Lujan-Fryns syndrome [MIM: } \\
\text { 309520]; Ohdo syndrome, X-linked } \\
\text { [MIM: 300895]; Opitz-Kaveggia } \\
\text { syndrome [MIM: 305450] }\end{array}$ & $\begin{array}{l}\text { dysmorphic features, intellectual disability, relative } \\
\text { macrocephaly, hypotonia, and constipation, partial } \\
\text { agenesis of the corpus callosum }\end{array}$ \\
\hline MED13 & Kinase & AD & $\begin{array}{l}\text { Intellectual developmental disorder } \\
61 \text { [MIM: 618009] }\end{array}$ & $\begin{array}{l}\text { intellectual disability and/or developmental delays, } \\
\text { including speech delays or disorders, autism }\end{array}$ \\
\hline MED13L & Kinase & AD & $\begin{array}{l}\text { Mental retardation and distinctive } \\
\text { facial features with or without cardiac } \\
\text { defects (MIM: 616789); } \\
\text { Transposition of the great arteries, } \\
\text { dextro-looped 1 (MIM: 608808) }\end{array}$ & $\begin{array}{l}\text { delayed psychomotor development, poor speech } \\
\text { variable penetrance of cardiac malformations }\end{array}$ \\
\hline MED17 & Head & AR & $\begin{array}{l}\text { Microcephaly, postnatal progressive, } \\
\text { with seizures and brain atrophy } \\
\text { (MIM: 613668) }\end{array}$ & $\begin{array}{l}\text { microcephaly, postnatal progressive, with seizures } \\
\text { and brain atrophy }\end{array}$ \\
\hline MED23 & Tail & AR & $\begin{array}{l}\text { Mental retardation, autosomal } \\
\text { recessive 18 (MIM: 614249) }\end{array}$ & mild to moderate ID, no dysmorphic \\
\hline MED25 & Unassigned & AR & $\begin{array}{l}\text { Basel-Vanagait-Smirin-Yosef } \\
\text { syndrome (MIM616449) }\end{array}$ & $\begin{array}{l}\text { severely delayed psychomotor development } \\
\text { resulting in intellectual disability, as well as variable } \\
\text { eye, brain, cardiac, and palatal abnormalities. }\end{array}$ \\
\hline MED27 & Head/ Tail & AR & $\begin{array}{l}\text { Current report } \\
\text { global developmental delay, central hypotonia, } \\
\text { spasticity, dystonic movements, cerebellar } \\
\text { hypoplasia, epilepsy, and cataract }\end{array}$ \\
\hline
\end{tabular}

AD, autosomal dominant; $A R$, autosomal recessive; $X L, X$-linked 